RESIDENT

\& FELLOW

SECTION

Section Editor

Mitchell S.V. Elkind,

MD, MS

Parayil Sankaran Bindu, MD

Jerry M.E. Kovoor, MD

Rita Christopher, MD

Address correspondence and reprint requests to Dr. Parayil Sankaran Bindu, Department of Neurology, NIMHANS, Bangalore, India

drpsbindu@yahoo.co.in

\title{
Teaching NeuroImages: MRI in maple syrup urine disease
}

Figure 1 T2-weighted MRI demonstrates elevated signal intensity of white matter in the thalamus, globus pallidus, and posterior limb of the internal capsule (A); midbrain (B); and pons and cerebellar white matter (C)

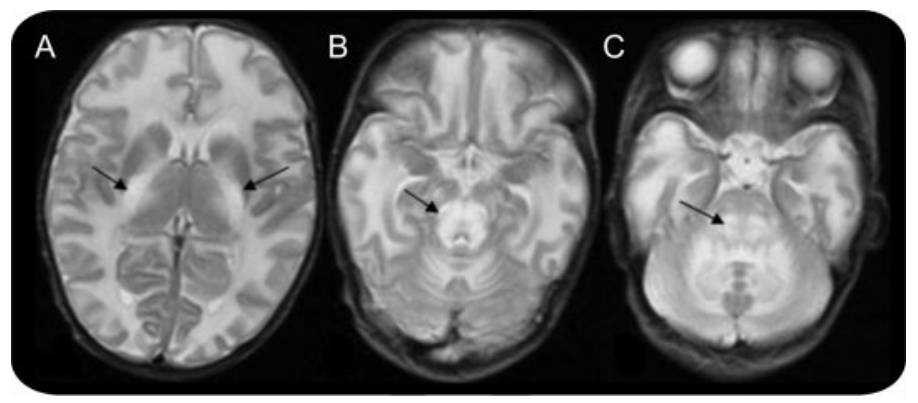

A baby girl, born normally to consanguineous parents, presented on the fifth postnatal day with poor feeding, lethargy, and seizures. Examination

$\begin{array}{ll}\text { Figure } 2 & \text { Diffusion-weighted images with } \\ & \text { corresponding apparent diffusion } \\ & \text { coefficient maps demonstrate } \\ & \text { restricted diffusion in the central } \\ & \text { part of the centrum semiovale (A, D); } \\ \text { posterior limbs of the internal } & \text { capsules and thalami (B, E); and pons } \\ \text { and cerebellar white matter (C, F) }\end{array}$

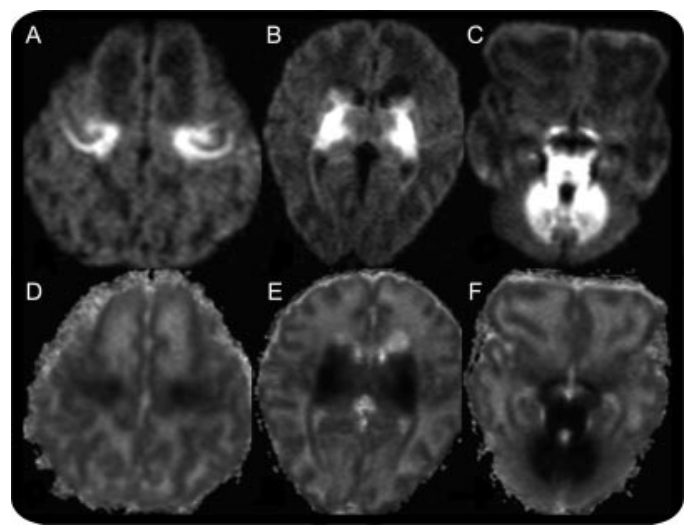

on the 10th day showed hypotonia and poor neonatal reflexes. Tandem mass spectroscopy showed elevated branched chain amino acids suggesting maple syrup urine disease (MSUD). MRI on day 14 revealed findings typical of MSUD (figures 1 and 2). ${ }^{1,2}$ The characteristic pattern of restricted diffusion, attributed to intramyelinic edema, corresponds to areas that are myelinating at birth. Unmyelinated areas show vasogenic edema. A similar pattern of restricted diffusion is seen in nonketotic hyperglycinemia and Canavan disease.

\section{REFERENCES}

1. Sakai M, Inoue $\mathrm{Y}$, Oba $\mathrm{H}$, et al. Age dependence of diffusion-weighted magnetic resonance imaging findings in maple syrup urine disease encephalopathy. J Comput Assist Tomogr 2005;29:524-527.

2. Jan W, Zimmerman RA, Wang ZJ, Berry GT, Kaplan $\mathrm{PB}$, Kaye EM. MR diffusion imaging and MR spectroscopy of maple syrup urine disease during acute metabolic decompensation. Neuroradiol 2003;45:393399. 


\title{
Neurology
}

\author{
Teaching NeuroImages: MRI in maple syrup urine disease \\ Parayil Sankaran Bindu, Jerry M.E. Kovoor and Rita Christopher \\ Neurology 2010;74;e12 \\ DOI 10.1212/WNL.0b013e3181ca0101
}

This information is current as of January 18, 2010

\section{Updated Information \& Services}

\section{References}

Subspecialty Collections

Permissions \& Licensing

Reprints including high resolution figures, can be found at: http://n.neurology.org/content/74/3/e12.full

This article cites 2 articles, 0 of which you can access for free at: http://n.neurology.org/content/74/3/e12.full\#ref-list-1

This article, along with others on similar topics, appears in the following collection(s):

All Pediatric

http://n.neurology.org/cgi/collection/all_pediatric

Amino acid

http://n.neurology.org/cgi/collection/amino_acid

DWI

http://n.neurology.org/cgi/collection/dwi

Metabolic disease (inherited)

http://n.neurology.org/cgi/collection/metabolic_disease_inherited

MRI

http://n.neurology.org/cgi/collection/mri

Information about reproducing this article in parts (figures,tables) or in its entirety can be found online at:

http://www.neurology.org/about/about_the_journal\#permissions

Information about ordering reprints can be found online:

http://n.neurology.org/subscribers/advertise

Neurology ${ }^{\circledR}$ is the official journal of the American Academy of Neurology. Published continuously since 1951, it is now a weekly with 48 issues per year. Copyright. All rights reserved. Print ISSN: 0028-3878. Online ISSN: 1526-632X.

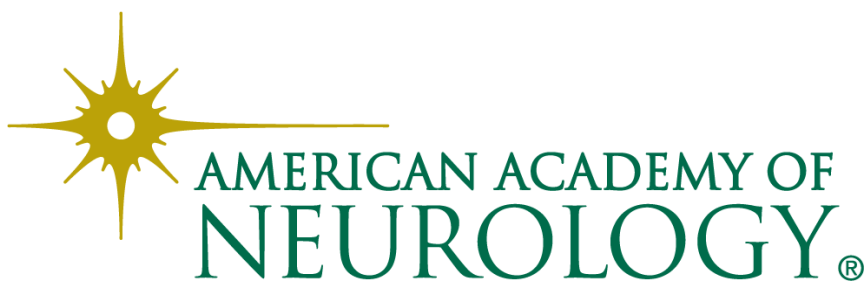

